\title{
Comparison between Predicted Rock Mass Classes and Actual Rock Mass Classes in Headrace Tunnel of Upper Mai Hydroelectric Project, Nepal
}

\section{Kanchan Chaulagai}

Abstract: This study involves comparison of predicted rock mass classes in design stage with actual rock mass classes of headrace tunnel of Upper Mai Hydroelectric Project. The total length of headrace tunnel is $2070.52 \mathrm{~m}$. The lithology of the study area consists of gneiss, schistose gneiss and mica schist. The rock mass classifications, Q-system were used to predict rock mass classes during the design phase as well as for classify rock mass during excavation of headrace tunnel. The applicability and validity of proposed classification has been checked by comparing the prediction with actual observation after completion of excavation. It was found that the predicted classes does not exactly matches with the actual rock masses as a results effecting in construction time as well as in cost and economy of the project.

Keywords: Comparison, actual rock mass, predicted rock mass, headrace tunnel, Geology, Nepal

\section{Introduction}

$\mathrm{T}$ he conditions of rock mass that encounter during the construction of underground works plays a vital role in finalizing the cost and required time for completion (Panthi and Nilsen, 2007). Due to this fact, several alternative routes are looked during the studies stages to find out the best solutions. Although great effort is done in designing stage, there will be some degree of variation in between the predicted and actual rock mass condition since several parameters are involved in determining the quality of rock mass. However, this variation should be within acceptable limits knowing the facts that predicting underground geological condition in advance is not an easy task, so that excessive cost overruns and construction time required are in controlled (Panthi and Nilsen, 2007).

The Upper Mai Hydroelectric Project (UMHEP) is located in Ilam district in eastern development region of Nepal. The low pressure inverted D shape headrace tunnel of $2070 \mathrm{~m}$ in length has a cross- sectional area of $4.75 \mathrm{~m}^{2}$. Before the excavation of underground works, several studies were undertaken and alternative plans for different tunnel routes were studied to determine the most feasible solution. The overall cost of the project is highly dependent on the site geology. Prior to commencement of construction work, therefore, every effort is made to predict the site geology as accurately as possible. To enhance more, Upper Mai Hydroelectric Project had done 2D - Electrical Resistivity Tomography (ERT) survey at feasibility stage to find out actual rock mass condition of the project.

The main aim of the study reported, herein, is to compare predicted and actual geology encountered during tunnel construction and its significant effects. Due to the facts that the cost estimates are made on the basis of the predicted data and, therefore, significant deviation of actual geology from the predicted one can prove to be economically colossal and wreck the project during execution.

\section{General Geology of the Project Area}

Geologically, the project area is located approximately $20 \mathrm{~km}$ north of Main Central Thrust (MCT), and approximately $30 \mathrm{~km}$ southeast of Tamar Khola Thrust. The project lies in the Eastern Region of Nepal and falls in the Higher Himalayan crystal line zone (Fig.1). The lithology of the area is comprised of medium to coarse grained, thickly to very thickly foliated, medium strong mica-schist, gneiss, schistose gneiss and medium to coarse grained, thinly to thickly foliated, weak to medium strong schist, garnetiferous muscovite-boitite-Quartz schist of Precambrian age (Chaulagai, 2017). Besides the bedrock, the area is widely covered with loose deposits of quaternary formation. The quaternary deposits are mainly of three types: alluvial, colluvial and residual soil deposits.

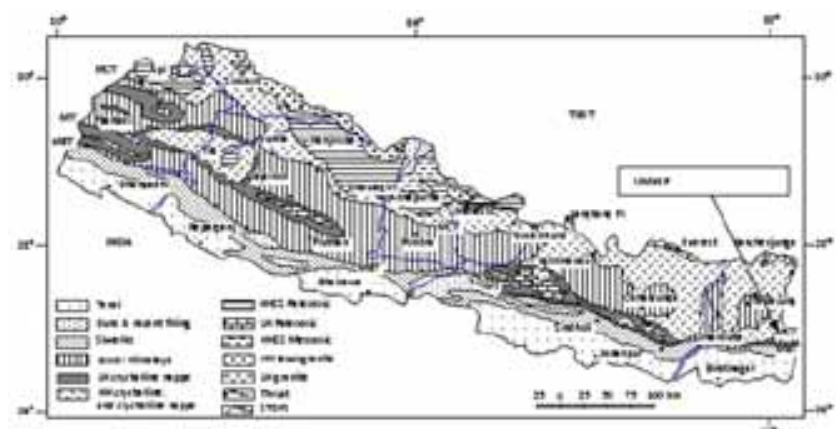

Figure 1: Geological Surface Mapping of Nepal (After Upreti and Le Fort, 1999)

\section{Design Data}

UMHEP is a run-of-river type project. Water is diverted from the Mai Khola, $500 \mathrm{~m}$ upstream of the confluence of Mai Khola and Rate Khola, by constructing a $3.0 \mathrm{~m}$ high permanent concrete weir (Upper Mai Hydroelectric Project, Design Report, 2009). During low flow season, when discharge in the Mai Khola is less than the design discharge, the water from the Rate Khola will be diverted through $148 \mathrm{~m}$ diversion tunnel to Mai Khola, $10 \mathrm{~m}$ upstream of the diversion weir at Mai Khola. 
The diversion weir has been designed as a simple free overflow weir without control gates. The water from the diversion weir is then diverted through the side intake on the left bank of the Mai Khola. The water then passes to the settling basin. The design discharge of the project is $3.88 \mathrm{~m}^{3} / \mathrm{s}$ at $32.52 \%$ exceedance flow. The total length of the waterways including headrace pipe, tunnel, and penstock and tailrace canal will be about $4.2 \mathrm{~km}$.

The headrace tunnel is $2 \mathrm{~m}$ wide and $2.5 \mathrm{~m}$ high, inverted D-shaped cross-section with $4.57 \mathrm{~m}^{2}$ cross section area. The total length of the headrace tunnel is $2070.52 \mathrm{~m}$. The velocity in the headrace tunnel will be less than $0.7 \mathrm{~m} / \mathrm{s}$ during design flow (Chaulagai, 2017).

The predicted rock types that are assumed to be encountered during the construction phase from inlet to outlet tunnel are gneiss, schistose gneiss and schist. It will also cross a shear zone near the inlet portal.

A characteristics property of the rock type in the tunnel area is summarized as below.

The gneiss is slightly to moderately weathered, grey, moderately to widely foliated, medium to coarse grained medium strong. It is hard and feldspar content is high. So the rock is similar to the feldspathic schist.

The Schistose gneiss is grey in color, slightly to moderately weathered, moderately to widely foliated, medium to coarse grained, strong to very strong.

The schist is moderately weathered, thinly to moderately foliated, medium to coarse grained and weak to medium strong. At some locations the biotite content is high.

An orientation of discontinuities (foliation/bedding) in average is $083^{\circ} / 27^{\circ}$ with joint sets of attitude $200^{\circ} /$ $75^{\circ}, 255^{\circ} / 65^{\circ}$ and $335^{\circ} / 65^{\circ}$. Estimated minimum and maximum overburden are $40 \mathrm{~m}$ at Thade Kholsi and $310 \mathrm{~m}$ at Bhakare respectively (Upper Mai Hydroelectric Project, Design Report, 2009). The proportions of rock type that were predicted during the design phase along the headrace tunnel are presented in Table 1.

\begin{tabular}{|l|l|c|}
\hline \multicolumn{1}{|c|}{$\begin{array}{c}\text { Rock } \\
\text { Type }\end{array}$} & \multicolumn{1}{|c|}{ Description } & Percentages \\
\hline Gneiss & $\begin{array}{l}\text { Grey, fresh to slightly weathered, } \\
\text { medium to thick bedded, } \\
\text { medium to coarse grained, } \\
\text { medium strong }\end{array}$ & 4 \\
Schist & $\begin{array}{l}\text { Grey, Moderately weathered, } \\
\text { coarse to very coarse grained, } \\
\text { weak to medium strong, biotite } \\
\text { dominant with fine garnet }\end{array}$ & 11 \\
\hline $\begin{array}{l}\text { Schistose } \\
\text { Gneiss }\end{array}$ & $\begin{array}{l}\text { Slightly to moderately } \\
\text { weathered, medium to coarse } \\
\text { grained, Strong to very strong, } \\
\text { feldspathic schist }\end{array}$ & 81 \\
\hline $\begin{array}{l}\text { Shear } \\
\text { zone }\end{array}$ & Crushed, very weak & 4 \\
\hline
\end{tabular}

Table 1: Rock type distribution along the headrace tunnel.
The rock mass classifications, Q-system were used to predict rock mass classes during the design phase of headrace tunnel and diversion tunnel. The rock mass at headrace tunnel of UMHEP is classifying as CI, CII, CIII, CIV and CV. The proportions of rock class that were predicted during the design phase along the headrace tunnel are presented in Table 2.

\begin{tabular}{|l|c|c|l|}
\hline Rock class & Q-Value & Percentage & Length \\
\hline I (Fair) & $>4$ & 11 & 227.76 \\
\hline II (Poor) & $1.0-4$ & 52 & 1076.67 \\
\hline III (Very Poor) & $0.1-1.0$ & 21 & 434.81 \\
\hline $\begin{array}{l}\text { IV (Extremely } \\
\text { Poor) }\end{array}$ & $0.01-0.1$ & 4 & 82.82 \\
\hline $\begin{array}{l}\text { V (Exceptionally } \\
\text { Poor) }\end{array}$ & $<0.01$ & 12 & 248.46 \\
\hline
\end{tabular}

Table 2: Predicted Rock class distribution along the headrace tunnel.

\section{Construction Data}

Limited site investigation, insufficient surface geological study brought deviation from tunnel design. Excavation classes observed during tunnel construction are different from those determined during tunnel design. The rock mass classifications, Q-system were used to predict rock mass classes during the design phase as well as for classify rock mass during excavation of headrace tunnel and diversion tunnel. Various excavation methods was used in UMHEP headrace and diversion tunnel during the time of excavation such as manual excavation, half face blast (bench blast) and full face blast. Half face blast/ Bench blast was adopted in the portal face, low stress area and weak geological condition. Full face blast was adopted in the good and very good geological condition. Similarly manually excavation was carried out in the very soft rock masses.

The design is reviewed i.e. shotcrete thickness, invert thickness and rock bolt length is revised as per geological conditions and stress measurements. It was determined that CI type rock requires support only in the form of spot rock bolts and shotcrete in fractured area only. Supports provided under CII are $1.5 \mathrm{~m}$ long rock bolts with c/c spacing of $1.3 \mathrm{~m} \times 1.5 \mathrm{~m}$ and $50 \mathrm{~mm}$ thick steel fiber shotcrete. Supports provided under CIII are $1.5 \mathrm{~m}$ long rock bolts with $\mathrm{c} / \mathrm{c}$ spacing of $1.1 \mathrm{~m} \times 1.2 \mathrm{~m}$ and 80 $\mathrm{mm}$ thick steel fiber shotcrete. Supports provided under CIV are $1.5 \mathrm{~m}$ long rock bolts with $\mathrm{c} / \mathrm{c}$ spacing of $1.0 \mathrm{~m} \mathrm{x}$ $1.0 \mathrm{~m}$ and $100 \mathrm{~mm}$ thick steel fiber shotcrete. Supports provided under $\mathrm{C} \mathrm{V}$ are $1.5 \mathrm{~m}$ long rock bolts with $\mathrm{c} / \mathrm{c}$ spacing of $1.0 \mathrm{~m} \times 1.0 \mathrm{~m}$ and $150 \mathrm{~mm}$ thick steel fiber shotcrete (Upper Mai Hydroelectric Project, Tunnel Inspection Report, 2013). In weak to very weak rock mass at class IV and V spilling bar and steel sets are used. The spacing of steel sets is determined as per site condition ranging from $90 \mathrm{~cm}$ to $130 \mathrm{~cm}$.

Reinforced Concrete lining was done in the poor rock mass at headrace tunnel, branch tunnel, Surge Shaft, near inlet portal and outlet portal. The percentage of concrete lining is $15.17 \%$. The proportions of rock class that were obtained during the construction phase along 
the headrace tunnel are presented in Table 3.

\begin{tabular}{|l|c|c|c|}
\hline Rock class & Q-Value & Percentage & Length \\
\hline I (Fair) & $>4$ & 11.33 & 234.60 \\
\hline II (Poor) & $1.0-4$ & 24.06 & 498.18 \\
\hline III (Very Poor) & $0.1-1.0$ & 37.41 & 774.56 \\
\hline $\begin{array}{l}\text { IV (Extremely } \\
\text { Poor) }\end{array}$ & $0.01-0.1$ & 23.74 & 491.54 \\
\hline $\begin{array}{l}\text { V(Exceptionally } \\
\text { Poor) }\end{array}$ & $<0.01$ & 3.46 & 71.64 \\
\hline
\end{tabular}

Table 3: Actual Rock mass distribution along the headrace tunnel.

\section{Differences between Predicted Classes and Actual Excavation Classes}

The accuracy of rock mass characterization, estimated required support, estimated construction time and estimated project cost solely depend on the accuracy of per construction phase geological investigation. The estimated data may not be similar to the construction data due to complexity of rock mass behavior, but this variation should be within the acceptable limits so that the tunnel cost and construction time are in control. The longitudinal profile of headrace tunnel that shows the differences between predicted rock mass class verses actual rock mass class are shown in figure 2.

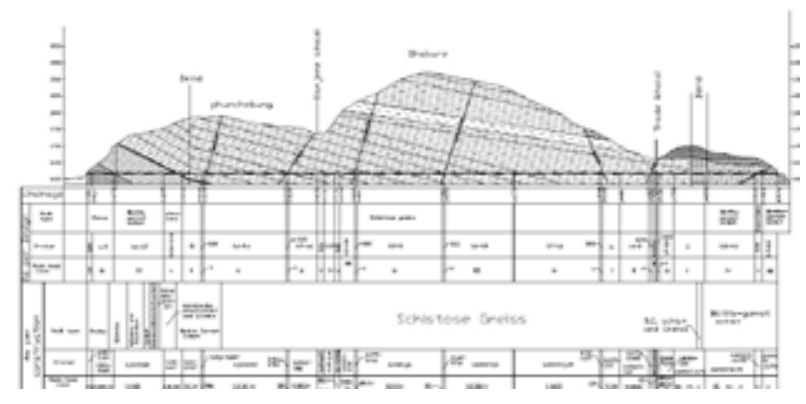

Figure 2: Longitudinal profile of Predicted verses Actual rock mass class.

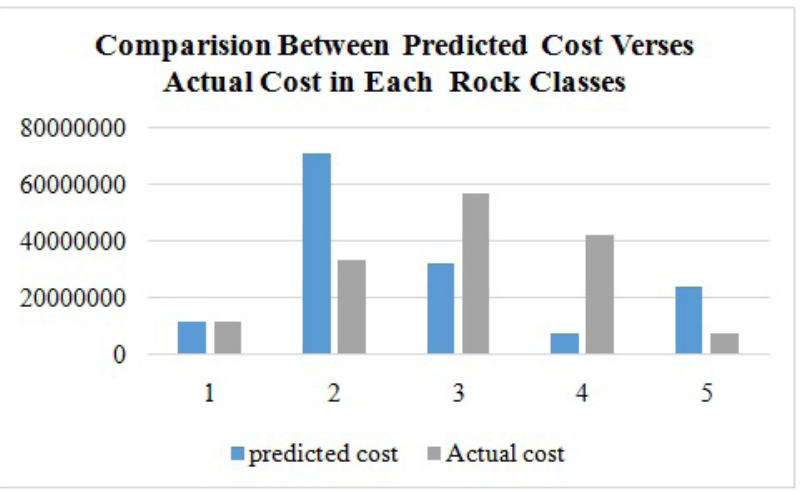

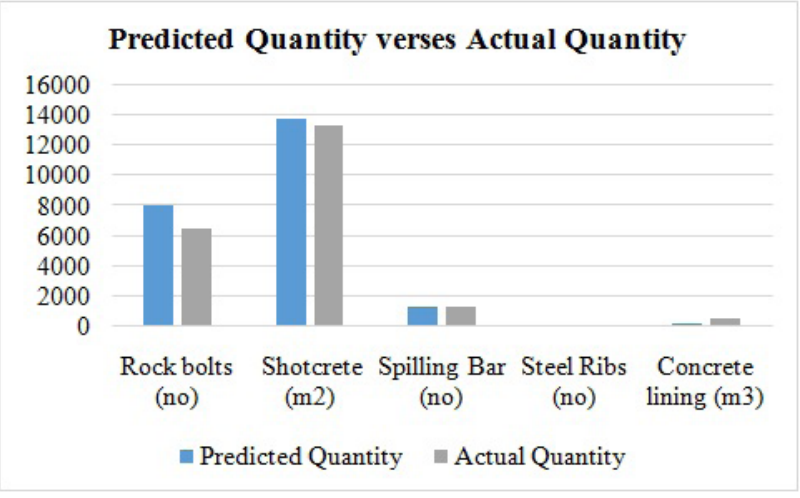
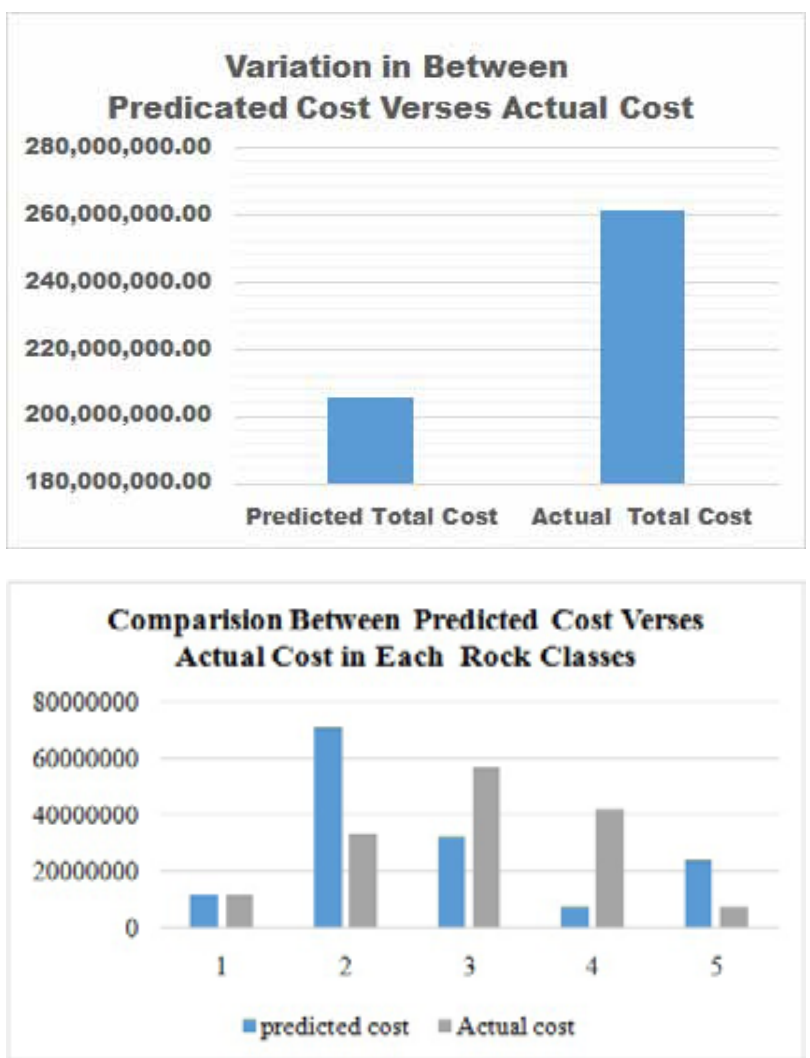

Figure 3: Comparison between predicted verses actual rock mass class, predicted cost verses actual cost in each rock class, predicted quantity verses actual quantity and variation in between predicted cost verses actual cost of UMHEP.

As shown in figure 3, there is a considerable difference between predicted and actual rock mass quality which ultimately influences the project costs. The difference in predicted rock mass class and actual rock mass class ultimately influence the consumption of support measures such as rock bolts, shotcrete, spilling bar, steel ribs and concrete lining. These variations in the consumption of support measure fluctuate the project cost and completion time.

\section{Conclusion}

The review of predicted rock mass quality verses actual rock mass quality and predicted rock support verses actual rock support in Upper Mai headrace tunnel shows considerable variations. These variations ultimately 
influence the project cost and time. To minimize the variation, the degree of geological and geotechnical investigation that is carried out at the time of preconstruction phase should be upgraded. As a result, initial investigation cost may rise slightly higher but it ultimately gives the accurate data, project cost and completion time.

Kanchan Chaulagai hold Master degree in Engineering Geology from Tribhuvan University in 2007. He has over nine years of experience in design, construction supervision and planning of tunneling in Nepal Himalaya from Far Wastern Region to Eastern Region. He works as a Tunnel Manager in Panchakanya Mai Hydropower Limited.

Corresponding E-mail: geologistkanchan@gmail.com

\section{References}

Chaulagai, K., 2017, Stabilization Measure Adopted for Controlling Landslide: A Case Study of Upper Mai Hydroelectric Project, Hydro Nepal, Vol.21, pp. 1114.

Chaulagai, K., 2017, Effectiveness of one way valve in the pressurized tunnel: a case study, Bulletin of Nepal Geological Society, Vol.34, pp. 59-64.

Mai Valley Hydropower Private Limited, 2009, Upper Mai Hydroelectric Project (9.98 MW): Design Report, Volume 1- Main Report, pp. 21-41.

Mai Valley Hydropower Private Limited, 2013, Upper Mai Hydroelectric Project: Tunnel Inspection Report, pp.7-14.

Panthi, K. K. and B. Nilsen, 2007, Predicted verses actual rock mass condition: a review of four tunnel project in Nepal Himalaya, Tunneling and underground Space Technology 22:173-184. 